\title{
Totalitarismo y filosofía
}

\author{
AGUSTÍN SERRANO DE HARO \\ Instituto de Filosofía, CSIC
}

\begin{abstract}
RESUMEN. El intento de expresar en fórmulas conceptuales tomadas de la tradición filosófica la novedad inaudita del totalitarismo contemporáneo arroja una luz peculiar sobre la cuestión tan debatida de la responsabilidad del pensamiento en la génesis de la catástrofe. Y la necesidad de recurrir a categorías centrales de la filosofía contemporánea -la noción de mundo de la vida, la del destino nihilista del mundo técnico-, para invertirlas y poner así bajo algún concepto la realización más genuina del totalitarismo, replantea a una luz también poco habitual la cuestión decisiva de si es posible, y cómo, que el pensamiento filosófico esté "a la altura" de lo que el siglo ha revelado. La obra de Hannah Arendt y la del pensador judío Emil Fackenheim guían el avance simultáneo en ambos problemas.
\end{abstract}

Abstract. The attempt to express in conceptual formulae taken from the philosophical tradition the unprecedented novelty of contemporary totalitarianism, casts a peculiar light over the much debated question of the responsibility of thought in the genesis of catastrophe. And the necessity of resorting to central categories of contemporary philosophy -the notion of world of life, of nihilistic destiny in the technical world- in order to invert them and thus place under some concept the most genuine form of totalitarianism, reconsiders in an also unusual light the decisive matter of whether it is possible, and how, that the philosophical thought can be "up to" what the century has revealed. The work of Hannah Arendt and of the Jewish thinker Emil Fackenheim guide the simultaneous advance in both problems.

\section{Prenotandos}

En distintas ocasiones se ha referido George Steiner al reto que supone para quienes en nuestro tiempo se dedican al cultivo de las humanidades el hecho de que haya habido seres humanos capaces de disfrutar, al caer la tarde, de Bach, Schubert o Goethe para retornar a la mañana siguiente a su "trabajo" diario de eliminar sistemáticamente seres humanos. El gran ensayista se ha mostrado escéptico de que la psicología o la sociología puedan ofrecer alguna explicación al respecto, pero ha sugerido que la misma filosofía tiene poco que decir, y no sólo a propósito de tan singular dualidad en las vidas de determinados individuos, sino también, y en general, en relación con la catástrofe política, histórica y humana de la que esa situación está tomada. La intención 
de este ensayo no es, desde luego, discutir el juicio de Steiner abogando por una contribución filosófica directa a la aclaración de los acontecimientos, bien sea en el plano de su génesis y sentido histórico, bien en el de una antropología que llegue a hacerse cargo de todo lo que el hombre es capaz de hacer al hombre. El propósito de mi trabajo es más bien mostrar que cabe, con todo, un esfuerzo de comprensión del totalitarismo y de su radical peculiaridad que se deja expresar en categorías del pensamiento, en categorías fundamentales del pensamiento filosófico. Tal enfoque no da respuesta, sin duda, a la llamada "gran cuestión del porqué" -de "por qué" se impuso en la realidad política de Europa el designio incondicional de aniquilar a la población judía-, ni tampoco, por supuesto, a la cuestión de "cómo" llegó a concretarse semejante designio. Y sin embargo, el recurso expositivo a ciertas categorías filosóficas generales, lejos de desactivar el impacto de los hechos al subsumirlos en lo eterno de la maldad humana o de la persecución histórica de minorías -o de esta precisa minoría-, sirve en medida nada despreciable, ni fácilmente sustituible, para tomar nota de qué es y sigue siendo lo incomprensible del proceso en cuestión, y en qué relación está ello con lo que tendemos a suponer que es comprensible y explicable.

Dos son las proposiciones básicas sobre las que se articula semejante intento de comprensión. En primer lugar: "Todo es posible", que incluye el "todo está permitido" pero que trasciende la máxima nihilista del personaje de Dostoyevski. En segundo lugar: "Todo es necesario", "todo está escrito", que incorpora una visión determinista del mundo pero que asimismo la trasciende. De hecho, el interés del análisis se concentra ante todo en perfilar cómo la política totalitaria llega a convertir en complementarios estos dos principios que a primera vista parecen opuestos, si es que no contradictorios. En todo caso, la aclaración de ambas fórmulas y de las más elaboradas que se alzan sobre ellas no implica nada parecido a una tranquila soberanía del pensamiento, que pudiera confrontarse con los hechos sin abandonar su discurso familiar. El sentido, o mejor, el sinsentido, el nauseabundo sinsentido al que da expresión la fusión de esas dos proposiciones modales sólo llega a captarse al hilo de los propios acontecimientos; se "lee" en ellos y se "comprende" únicamente en ellos, y en su término final y principio de interpretación que son los campos de concentración y exterminio. De suerte que las propias nociones de posibilidad, necesidad y totalidad, que entran en estas construcciones conceptuales, experimentan una transformación radical de sentido; no se trata ya de una última variación interna respecto del sentido que la tradición intelectual y política conocía de antes en alguna de sus formas, sino precisamente de otra cosa, de algo verdaderamente inédito, singular y espeluznante, que es lo que 
justifica en plenitud, como trataré de esbozar, la denominación de totalitarismo.

Lo que ya tiene poca justificación por mi parte es omitir que mi aportación en estas páginas se limita, en primer término, a la muy modesta de identificar, relacionar y prolongar los elementos y motivos teóricos que avalan la perspectiva esbozada en la extraordinaria reconstrucción del totalitarismo que llevó a cabo Hannah Arendt. A mi juicio, y pese a la condición temprana de la obra, el valor teórico de Los orígenes del totalitarismo y en particular el de su tercer libro no se ha resentido en lo esencial de la multiplicación incesante de la información histórica y de los debates teóricos ${ }^{1}$. El análisis de Arendt, en realidad tan reacio a la filosofía teórica, incluida la filosofía política, posee, empero, como también intentaré mostrar, una fuerza y una novedad interpretativas superiores a otras conceptuaciones sugeridas por destacados filósofos contemporáneos.

Al lado de este interés teórico por intentar exponer desde el lenguaje y desde las categorías de la filosofía el fenómeno totalitario, no podía faltar la meditación que discurre, por así decir, en la dirección contraria: la que expone la propia filosofía a la carga destructiva del totalitarismo, planteándose no sólo si cabe señalar a parte ante algún tipo de responsabilidad política o intelectual del pensamiento en la catástrofe, sino también, a parte post, si cabe una recuperación segura del pensamiento y de su tradición "a la altura" de la catástrofe acontecida. A estos otros fines la obra de Arendt sigue siendo de gran relevancia, máxime a la luz que algunos textos breves de los años cuarenta y cincuenta arrojan sobre el problema de la responsabilidad antecedente $^{2}$. En relación con la cuestión de la continuidad del pensamiento, he juzgado necesario, sin embargo, recurrir al pensador que con mayor insistencia ha requerido a la filosofía en las últimas décadas a confrontarse temáticamente con el Holocausto -pues Emil Fackenheim sí acepta el término de origen griego-. La obra mayor de Fackenheim: Reparar el mundo ${ }^{3}$ examina de modo extraordinariamente original en qué condiciones puede y debe producirse dicho contraste.

${ }^{1}$ The Origins of Totalitarianism, Nueva York, Harcourt Brace, 1951. Las citas remiten a la traducción española de Guillermo Solana -Los orígenes del totalitarismo, Madrid, Alianza, 1987que lo es de la segunda edición norteamericana revisada y ampliada de 1958. (En adelante abrevio esta obra en Los orígenes. Todas las restantes traducciones, salvo indicación en sentido contrario, son mías.)

${ }^{2}$ Reunidos en: Arendt, Essays in Understanding 1930-1954, Nueva York/San Diego/Londres, Harcourt Brace, 1994. (En adelante abrevio en Essays.)

3 To Mend the World, Nueva York, Schocken, 1982. Las citas remiten a la tercera edición: Bloomington/Indianápolis, Prensas Universitarias de Indiana, 1994. 


\section{Mundo de la vida e ideología totalitaria}

La reconstrucción arendtiana del totalitarismo pone el concepto de mundo en el centro de la consideración. Tanto es así que "el mundo", el mundo normalizado, la realidad no dominada, constituye a lo largo de toda la obra una noción operativa y un término de contraste, antes que una categoría tematizada que se someta a dilucidación explícita. Esta noción de mundo cobra su primer relieve teórico en la etapa anterior a la llegada al poder de las organizaciones totalitarias, en relación con la tesis de que los movimientos totalitarios de entreguerras fueron "los primeros partidos verdaderamente antiburgueses" $"$.

Los partidos y asociaciones políticas tradicionales representaban los intereses, por principio limitados, de las distintas clases o sectores sociales que convivían en el interior del Estado-nación. Los movimientos totalitarios, en cambio, se nutrieron básicamente de individuos atomizados y desclasados, que a consecuencia de las sucesivas crisis económicas habían perdido todo lugar en la realidad social, y que en consecuencia experimentaban su existencia individual como siendo del todo irrelevante, como superflua en el interior de la sociedad. La pretensión de organizar y movilizar estas masas populares, "residuos" de las antiguas clases sin excepción, tampoco respondía entonces a una política a la antigua usanza de objetivos limitados e intereses precisables, que de algún modo comportara la reintegración de las masas al mundo compartido y a la búsqueda del interés propio. La generación que había conocido las trincheras, había asociado la atrocidad vivida en el frente a la revelación de que el "mundo oficial", es decir, la propia sociedad burguesa de la moral humanitaria y el progreso colectivo, era en realidad un puro artificio que enmascaraba el completo desprecio por las vidas gastables de los individuos, y que por ello -más por esta hipocresía que por aquella crueldad- debía "pagar" un precio. Más allá de dudosas fascinaciones retóricas, el atractivo creciente de las nuevas organizaciones estará, según Arendt, en que, a través de todas sus mentiras -que fueron muchas y constantes-, se hacían fuertes en proclamar la única verdad de que el mundo oficial estaba amenazado de quiebra; de que el Estado-nación como integración, por conflictiva que fuese, de los distintos colectivos sociales, y como ámbito de coexistencia bajo el amparo de la ley de los distintos grupos de población, por desigual que fuese la protección a las minorías, no proporcionaba ya ningún marco estable de convivencia $-y$ por tanto tampoco permitía ningún verdadero statu quo entre los Estados euro-

${ }^{4}$ Los orígenes, 492. 
peos-. Mintieron sin límite pero asentados sobre esta visión certera de la ruptura del mundo institucional, que era, a la inversa, lo único que éste último, con todas sus verdades limitadas, se empeñaba en negar ${ }^{5}$.

De aquí también el que las organizaciones totalitarias, a diferencia de nuevo de los antiguos partidos, ofreciesen a sus adeptos no otra cosa que un mundo alternativo al reconocido; un mundo oculto y conspiratorio sobre el de la cotidianidad, que exigía una adhesión incondicional, absoluta, y que disolvía ya toda oposición entre vida privada y vida pública. Arendt describe con detalle la articulación interna de los movimientos en escalas superpuestas, o mejor, en capas puestas unas bajo otras, de un compromiso siempre creciente y de siempre mayor radicalismo. Para el mundo exterior sólo era visible la cara superficial del movimiento, las organizaciones frontales y propagandísticas, que eran la fachada ad extra que a su vez operaba como el dominio exterior de círculos más profundos del movimiento (los cuerpos de elite, sus jerarquías internas, la camarilla que rodeaba al Jefe), más aislados por tanto de la realidad externa. Al cabo, estos distintos círculos, caras o capas, funcionando como vías de contacto mediato entre ellos, $\mathrm{y}$, así, como aislantes progresivos respecto de la realidad, se cohesionaban internamente por la asunción en la práctica de máximas más y más contrarias al mundo exterior, más desafiantes respecto de la moral heredada y aceptada: "tú insultarás y denunciarás a tus convecinos, tú saquearás, tú matarás".

Se alcanza así una presentación inicial, previa al acceso al poder, de la primera fórmula descriptiva del totalitarismo. Lo que estaba en el punto de mira de los movimientos totalitarios era, en efecto, el "todo", el mundo compartido de la coexistencia humana, el mundo intersubjetivo de la vida, cuyas tramas y estructuras institucionales tradicionales se habían quizá roto, pero que en todo caso era a la vez una realidad social y cotidiana sostenida en prácticas morales de convivencia que podían deliberadamente quebrarse. La posibilidad total que se proclamaba y se pretendía respecto de este mundo íntegro de la vida -"todo es posible"- era entonces la de su subversión plena, la de su dominación completa, hasta más allá quizá de la posibilidad de seguir reconociendo en él "el mundo eterno de los seres humanos"6. La segunda categorización formal: "Todo es necesario", permite ahora dar mayor concreción y claridad a este primer acercamiento.

La aguda interpretación que Arendt propone de la fórmula "todo es necesario" guarda relación directa con el componente ideológico del nazismo -mu-

${ }^{5}$ Vid. Los orígenes, cap. 10, y también “Approaches to the «German Problem»”, en: Essays, p. 111-113.

${ }^{6}$ La expresión es de un superviviente de los campos de concentración: Imre Kertész, Un instante de silencio en el paredón. El Holocausto como cultura, Barcelona, Herder, 1998, p. 23. 
tatis mutandis del stalinismo-. También Fackenheim defendió en un breve ensayo que la respuesta última al porqué del nazismo pasa inevitablemente por el afán propio de los alemanes de vivir con una ideología, vivir en una $\mathrm{Wel}$ tanschauung; anhelo de tener una visión global, cerrada del mundo y de la Historia, sin que importe el que la filosofía y aun el sentido común nieguen estatuo cognoscitivo a semejantes construcciones ${ }^{7}$. Arendt propugna, en cambio, una noción de ideología que es privativa del totalitarismo y que se opone al concepto de inspiración diltheyana de "visión del mundo" totalitaria invoca, desde luego, un principio "eterno" que pretende ser indistintamente el contenido último de la Naturaleza y el sentido irrevocable de la Historia: ley de la lucha de las razas humanas por la supervivencia y supremacía, en la versión nazi; ley del aplastamiento de las clases sociales moribundas por las emergentes, en la stalinista. Más que un complejo unitario de representaciones y de creencias, hay aquí una única idea a la que toda la variedad del mundo se reduce, un "supersentido" omniabarcante bajo el que se coloca toda la multiplicidad de la existencia humana. Pero Arendt pone el acento principal en que esta única idea, en lugar de un principio orientador con vocación de permanencia en el tiempo, constituye más bien una "ley del movimiento universal", al que la organización totalitaria pretende ajustarse en orden a potenciar, a promover, a acelerar la marcha "sobrehumana" de la Historia.

Pues el racismo y el clasismo biologicistas sólo tienen ojos para la supuesta necesidad omnímoda que hace surgir los pueblos, las razas, las sociedades, y que los lleva a prevalecer o a sucumbir. Poco importa aquí cómo sean en verdad el mundo o los hombres, o cómo deban en justicia ser. Únicamente cuenta la dinámica subyacente de una Historia natural que discurre por debajo de la experiencia real o posible de los hombres y que es inmune a ésta; que repudia todo sentido y validez limitados para manifestarse sólo en violencia perpetua, en dominación y extinción colectivas. Pero es a esta matriz sobrehumana de la Historia a la que aspira "sinceramente" a adecuarse la organización totalitaria, como si ella pudiera derivar de la omnipotencia de la Naturaleza, en la que cree, la capacidad ilimitada de movilización de los hombres y transformación de la realidad social que ha de poner por obra.

El totalitarismo encarna por tanto una ideología en un sentido bien distinto de la mera inspiración en una visión global del mundo más o menos precisa entre varias posibles. La novedad no está en el racismo como doctrina, ni,

${ }^{7}$ Vid. "Philosophical Considerations and the Teaching of the Holocaust", en: E. Fackenheim y R. Jospe (eds.), Jewish Philosophy and the Academy.

${ }^{8}$ Para todo lo que sigue es asombrosamente lúcido "On the Nature of Totalitarianism. An Essay in Understanding", en la recopilación citada, en especial p. 338-349. Este largo artículo es la base del cap. 13 de Los orígenes, añadido a la segunda edición. 
claro está, en el antisemitismo (si es verdad, de acuerdo con Fackenheim, que "los nazis eran racistas porque eran antisemitas, no al revés"), sino más bien en la conversión del racismo en único principio "en movimiento", que, se siga de ello lo que se siga, da forma al mundo alternativo, rige el asalto al mundo normalizado y acelera la fusión entre ambos. A esta luz, lo de menos era la argumentación verosímil de la ideología, cosa que implicaba eo ipso rebajarla a una opinión más en el confuso teatro moderno de las discusiones; lo de menos también, el hallazgo de valedores pseudofilosóficos de ella. Lo único relevante estaba en la activación de esa premisa única como principio infinito de movimiento que reorganizase la realidad de acuerdo con criterios incondicionales de raza; que lo hiciese primero con la vida de los militantes y del movimiento, después con la estructura del Estado conquistado, y por fin con la totalidad de la sociedad dominada, en todas sus dimensiones públicas y privadas. Sólo el desencadenamiento del veredicto ideológico "todo es necesario", "todo está escrito en la Naturaleza y predeterminado en la Historia", estaba así llamado a revelar, en el interior del mundo de la vida, que efectivamente "todo puede ser posible": que todos los hombres y todo el mundo humano puede ser mirado como materia y material de poder a disposición del movimiento. La conciencia de ser ejecutores objetivos de un proceso ineluctable, que por ello está a prueba de toda consideración moral y no es sometible a ulterior discusión, confería así a los actos criminales un aspecto peculiar que parecía escapar a su valoración normal en términos de una inmoralidad trasgresora o incluso de un nihilismo amoral; igual que el desprecio hacia los cálculos limitados de utilidad y hacia toda ventaja personal de los adeptos tornaba inadecuadas las explicaciones psicológicas por un puro afán personal de poder. El totalitarismo en el poder, que pasaré a continuación a examinar, ofrece una revalidación del sentido de ambas fórmulas y de su íntima conexión, a la vez que implica un primer salto cualitativo en la comprensión de su alcance.

\section{Un nuevo orden de la "verdad"}

En la interpretación de Arendt, la política formalmente totalitaria no se inicia en Alemania hasta fecha tan tardía como finales de 1938. En el caso del otro totalitarismo, el stalinista, no lo sería hasta 1930, es decir, sólo después de que la lucha en el interior del partido bolchevique se hubiese resuelto por completo a favor de Stalin. Pero a diferencia de lo que sucedió en la Alemania nazi, el totalitarismo stalinista se interrumpió por las exigencias del esfuerzo bélico, para reanudar al acabar la guerra las persecuciones sistemáticas de 
población y las purgas periódicas que lo caracterizaban. Mi exposición se atendrá en todo caso al criterio de Arendt de ver en el nazismo la realización (más) acabada del totalitarismo, en la medida en que Auschwitz está con el Gulag en una relación análoga a la del Infierno en la Tierra con un Purgatorio de deportación y abandono.

En esta perspectiva la fecha clave de referencia es en efecto noviembre de 1938; el punto de inflexión de la violencia del Estado sobre la población judía, que, al entender de Arendt, viene a sugerir una novedad sustancial respecto de toda la Historia de Occidente en lo que hace al empleo político de la violencia9. Y es que aun en los casos extremos de terror ejercido por tiranías o desencadenado por partidos revolucionarios, la violencia política responde a una secuencia de sentido que hace que su aplicación tienda a regularizarse y limitarse una vez alcanzados los objetivos de conquista o conservación del poder. En la Alemania nazi esta etapa, singularmente cruel, de violencia instrumental y selectiva, ordenada a un fin, había concluido relativamente pronto -1935-, y había cumplido con creces los objetivos de eliminación de toda resistencia organizada, aterrorización de desafectos e incluso desahogo a una cierta revancha social en los primeros campos de concentración. La consolidación interna y externa del régimen, en lugar de significar -de acuerdo con leyes "naturales" de autoconservación política- el punto de atenuación o equilibrio de la violencia y el inicio de la reconducción legal de su ejercicio, significó ahora, sin embargo, el punto de partida hacia los verdaderos objetivos de la dominación total y la política ideológica.

En esta nueva escala del terror la elección de las víctimas prescindía ya por completo de toda referencia a individuos, a personas individuales en razón de su conducta, posición social o siquiera su pensamiento, y pasaba a ocuparse de sectores enteros de la población tomados en conjunto en razón de características puramente objetivas, biológicas y raciales; en razón de lo que "eran" y por serlo. Es ahora, pues, cuando la ideología en sentido totalitario se torna el motor efectivo de la política del movimiento, al convertir a individuos sin delito en delincuentes objetivos que combatir en virtud de la ley suprahistórica que los señalaba como enemigos sentenciados; es ahora cuando se concibe, además, la posibilidad de una persecución ilimitada, plenamente ilegal por desbordar el marco institucional del propio Estado controlado ${ }^{10}$, mas en sí misma carente de todo margen de arbitrariedad o discrecionalidad. El universo

\footnotetext{
${ }^{9}$ Op. cit., 631-639, 689-695. Vid. también "On the Nature of Totalitarianism: An Essay in Understanding”, en: Essays, p. 339-360

${ }^{10}$ El programa oficial del partido para la población "no aria" estaba más que cumplido; las leyes de Nuremberg, en plena vigencia. Al desbordamiento del marco legal corresponde la conocida estructura de "Estado dual" de los regímenes totalitarios, en que la policía política, sustraída
} 
ficticio de la ideología totalitaria se da así a conocer en su "verdad" a través de un terror implacable que quiere ser el contenido de la política del movimiento y la voz infalible de la Historia. O dicho en otras palabras, el nexo de unidad entre el todo es posible y el todo es necesario es una violencia sistemática, objetivada, que se desprende de toda referencia a fines para ser ella el fin al que se sacrifican personas.

Ahora bien, esta precisa comprobación conduce a la tesis de que "la filosofía del hitlerismo" -según el giro de Lévinas- revela en realidad -y contra el juicio del propio Lévinas en 1934- una pretensión tan afilosófica como la tradición entera de pensamiento no había podido siquiera sospechar, un fondo más extrafilosófico de lo que el pensamiento occidental habría creído siquiera posible. Y es que bajo el sistema ideológico que el terror pone en movimiento, lo que late es la convicción de poder mirar todo hecho como fabricable y toda la realidad como fabricada; al extremo mismo de abolirse la diferencia entre lo que es (o era) verdadero y lo que es (o era) falso. Así, de la lucha eterna de las razas responde sólo el orden de un mundo ahora en construcción, que permite acabar con razas inferiores para engendrar la superior. Así también, la prueba última de la condición inmunda de la población judía será, más tarde, que se la puede sacar del mundo y reducir de hecho a condición infrahumana ${ }^{11}$. La realidad, pues, se recrea al recibir una nueva consistencia, una nueva coherencia que no tolera a su lado ningún otro hecho, presente o pasado, empírico o "ideal”. Esta fusión de los dos principios que hemos venido señalando, en un tercero según el cual la verdad es fabricable pues la realidad entera lo es, se encuentra más allá de lo aprehensible con nociones y oposiciones filosóficas ${ }^{12}$. Habría acaso que hablar de algo así -Arendt

a toda jerarquía institucional, se convierte en el núcleo del poder, su brazo ejecutor y la encarnación de la ley.

${ }^{11}$ Igual que, en otro orden de cosas, la prueba de que Alemania combatía en una guerra de supervivencia, y no de agresión, era la voluntad de reducirla a escombros si era incapaz de brindarle la victoria al Führer. No se olvide, que Arendt tiene sumo cuidado en destacar que la raza de señores no eran los alemanes, ni siquiera los arios, sino los arios SS: "Los nazis no pensaban que los alemanes eran una raza de señores a la que pertenecía el mundo, sino que los alemanes debían, como todas las demás naciones, ser dirigidas por una raza de señores, la cual se hallaba solamente a punto de nacer. El amanecer de la raza de señores no eran los alemanes, sino las SS", Los orígenes, 618.

12 A esta luz parece más que discutible el intento de Lévinas, que apunta a una suerte de rebelión contra el dualismo arrastrado por la filosofía clásica y moderna, por la tradición cristiana y por la liberal; dualismo éste que, separando siempre el cuerpo del alma o de la mente, habría estado ciego para la adhesión primaria, plena, irrevocable, del yo a su cuerpo y a su comunidad consanguínea. Así es como se describe la "secreta nostalgia del alma alemana" que el hitlerismo habría por fin venido a satisfacer. Vid. "Quelques réflexions sur la philosophie de l'Hitlerism", en: Esprit 26 (1934). Hay trad. española de José Ramón Iraeta, en: Beltrán, M., Mardones, J.M., y Mate, R. (eds.) Judaísmo y límites de la Modernidad, Barcelona, Ríopiedras, 1998. 
no lo hace- como una "verdad" íntegramente contra-fáctica, en el sentido literal de que no admite ninguna realidad previa independiente de la ficción ideológica y de que, acto seguido, hace valer ésta última por sobre todo hecho y en contra de los hechos existentes ${ }^{13}$. Por decirlo de un último modo, la verdad y su prueba se remiten a los hechos, los cuales han desaparecido y se engendran ya sólo por la violencia. No hay ninguna concepción filósofica de la verdad, teórica o pragmática, ni ninguna visión prefilosófica del mundo, germana o no, en que tenga sitio esta fabricación contra-fáctica de "la verdad", que sólo es posible por el mismo terror que la trae a la realidad y la impone en ella.

Pero queda todavía un último salto de cualidad, que es el que separa a la ideología puesta en movimiento ciego desde el poder, del universo alternativo ahora ya plenamente logrado. Este universo otro no se deja expresar siquiera como un designio racista contra-fáctico que es convertido en el único contenido del mundo. $\mathrm{Y}$ aunque tampoco hay a fortiori ninguna concepción filosófica o prefilosófica de la realidad en que tal universo tenga cabida, ocurre otra vez que categorías filosóficas invertidas resultan singularmente adecuadas para expresar el retorcimiento definitivo del "todo es posible" con el "todo es necesario".

\section{La realización completa del sinsentido}

Hay una coincidencia notable en los testimonios de los supervivientes a la hora de describir el campo de concentración y de exterminio como un universo aparte que se cierra sobre sí mismo con plena coherencia y que es otro respecto de nuestro mundo. Sin duda es demasiado fácil explicar esta concordancia como el resultado de una metáfora brillante que termina olvidando el exceso expresivo del que proviene. Pero veamos si no es, al contrario, demasiado difícil conceptuar bajo categorías límite del pensamiento la realidad de este mundo alternativo ya construido, ya realizado. En su autobiografía, Elie Wiesel por ejemplo evocaba su impresión tras los primeros días de estancia en Auschwitz con las siguientes palabras: "Lo veo todo, lo oigo todo, lo capto todo, lo grabo todo en la memoria, pero sólo más tarde intentaré ordenar las sensaciones, los recuerdos. Mi estupefacción, por ejemplo, al descubrir fuera del tiempo, en otro tiempo, junto al universo otro universo paralelo, una creación en el interior de la Creación, con sus leyes, sus hábitos, sus costumbres, sus estructuras y su lenguaje. En ese universo hay hombres que sólo existen para matar y otros que sólo existen para morir. Y el sistema funciona con ejemplar eficacia. Los atormentadores atormentan y destrozan su presa, los torturadores

13 Vid. Essays, 352-355. 
torturan seres humanos a los que ven por primera vez, los degolladores degüellan a sus víctimas sin ni siquiera mirarlas, las llamas suben al cielo y nada logra detener el mecanismo"14. Y el precoz estudiante de mística judía que había dejado de ser Wiesel al ser puesto en el correspondiente vagón de ganado, confiesa: "En el fondo de mi ser, sé, siento que ningún cabalista ha podido prever nunca este lugar"15.

El estudio de Arendt, que en tantos aspectos se adelantó a la conciencia de su tiempo, se detenía primero en algunas características, por así decir "objetivas", que estaban a la base de esta impresión insuperable de estar en un universo alternativo: estatuto fuera de toda legalidad general o especial y fuera de todo control o supervisión; aislamiento completo del campo del entorno físico y humano en que se supone que estaba, incluido el escenario bélico; y, quizá más que ningún otro rasgo, carácter antiutilitario del campo, ausencia de finalidad práctica que justificase su existencia o su regulación interna, que más bien era una preeminencia del fin absoluto del exterminio sobre cualquier otra consideración, incluida la victoria militar en la guerra. Pero cada una de estas características objetivas puede y debe hacerse corresponder con fases en el proceso de destrucción de los internos en el campo, que Arendt, con la extraña claridad de una pura dilucidación conceptual, ordenaba en tres niveles o etapas ${ }^{16}$. Con la deportación en masa se había consumado ya "la destrucción de la persona jurídica”, comoquiera que el traslado forzoso no era pena fijada por ninguna autoridad judicial sino la toma de posesión de conjuntos enteros de población (primera etapa, que pone seres humanos fuera de toda ley). El internamiento procedía entonces a "la destrucción sistemática de la persona moral”, entendiendo por tal la cancelación del ser humano como ser-en-el-mundo, la destrucción no ya de la libertad sino de todas sus precondiciones (segunda etapa, que pone fuera del mundo de los hombres a quienes se había puesto fuera de toda ley). Así, el nombre individual era sustituido por un número de interno, el trabajo extenuante se ordenaba no a un rendimiento sino a la eliminación y al escarnio -no era esclavización-, la supervivencia pasaba de modo casi forzoso por el abuso sobre otros más débiles, y la obligación de contemplar públicamente la tortura, cuando no de colaborar en tareas de administración o de eliminación, formaba parte del inenarrable día a día, siempre en la vecindad perceptible de las fábricas de la muerte. El espacio mínimo de sentido que una existencia personal requiere había sido suprimido (los hombres se amontonaban unos sobre otros, sin un medio objetivo entre ellos de

${ }^{14}$ Todos los torrentes van a la mar-trad. de Manuel Serrat Crespo-, Madrid, Anaya-Muchnick, 1996, p. 94.

15 Ibid.

16 Vid. Los orígenes, 665-678. 
cosas poseídas y útiles asegurados), y el horizonte de tiempo había desaparecido al romperse todo nexo de motivación con el pasado y quebrar todo proyecto de futuro. No obstante lo cual aun después de destruido existenciario a existenciario el ser-en-el-mundo y después de destruida la existencia personal, había una tercera y última fase en que la propia individualidad del sujeto humano, su conciencia de sí como perteneciente a la especie humana, era término final del asalto (tercera etapa, que deja como fuera de la especie de los hombres a quienes se ha puesto fuera del mundo de los hombres). El individuo destruido en cuerpo y alma pero aún vivo, devenía finalmente mero haz de reacciones al terror, sustituible a capricho por cualquier otro manojo idéntico; devenía así mero especimen humano, la imagen cabal del perro pavloviano, o bien una "máquina vegetativa", el llamado "musulmán" que había terminado por perder la espontaneidad elemental del cuidado de la propia vida y había sido convertido en muerto viviente. Y en cierto modo este escalón terminal del proceso de internamiento se correspondía de inmediato, según la doble faz del campo, con el proceso de exterminio; con una administración masiva y mecánica de la muerte que entrañaba la deshumanización límite del morir, hasta el despojo del propio cadáver. Muerte que se aplicaba a seres humanos como si a todos los efectos fuesen ganado, casi un proceso químico a escala industrial.

Fackenheim hace suya la comprensión de Jean Améry, y se refiere a la "lógica de la destrucción" que atraviesa el universo paralelo, que lo sostiene y lo mantiene unido igual que la lógica de conservación rige en los "mundos normales"17. Es ésa una lógica omniabarcante, consciente y reflexionada, por cuanto dispone las formas no sólo de destruir seres humanos, sino de colocarlos ante su propia autodestrucción física y moral. De los análisis de Arendt puede extraerse a su vez una suerte de axioma global del universo concentracionario, que vendría a ser la síntesis consumada del "todo es posible" con el "todo es necesario". Pues en la realidad cabe un universo hecho por el hombre, en el cual los hombres y la condición humana como tal son superfluos, en que están de más y son destruibles sin resto. El mundo alternativo emerge de esta supresión in individuo de los seres humanos e in genere de su condición humana, y sólo consiste en ella, en la trasgresión minuciosa del límite que opera la distinción entre vida y muerte, hombre y condición inhumana. Mundo hecho necesario para hacer destruible la condición humana.

A fin de conceptuar este "mundo" a la luz de la lógica de la destrucción, Fackenheim ha recurrido con admirable osadía al giro acuñado por Heidegger de "anti-mundo" o "in-mundo". Con la expresión Un-welt, el filósofo alemán

17 To Mend the World, 206-215. 
describía y valoraba el mundo técnico posterior a la Segunda Guerra Mundial, entregado al "ciego frenesín" que consuma el abandono de la Presencia del $\mathrm{Ser}^{18}$. Con ella, el pensador judío se refiere, en cambio, a este otro mundo oculto bajo la Segunda Guerra, que producía sin cesar el silencio terminal del "musulmán” y los gritos de los niños arrojados vivos a las llamas, mundo de Auschwitz o de Treblinka que con "ciego frenesí" estaba diseñado para engendrar a la vez ese silencio y estos gritos. Tal es el absoluto "antimundo", que, visto desde los ejecutores, es "un mundo en que la tortura y el asesinato estaban ordenados, y la voz que lo ordenaba -su última fuente, un Führerbefehl

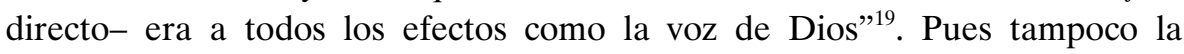
filosofía había soñado una posibilidad próxima a ésta.

En los textos de Arendt, y sin que esto implique el reconocimiento de una influencia que no es afirmable, cabe observar que es la filosofía tardía de Husserl la que puede prestar el giro categorial que, invertido, permite una cierta descripción del anti-mundo: en lugar de mundo cotidiano de la vida, "mundo de muertos", "mundo cotidiano de la muerte": "El punto está en que Hitler no era como un Genghis Khan, y no era peor que otros grandes criminales sino enteramente diferente de ellos. Lo que carece de precedente no es el asesinato en sí mismo ni el número de víctimas ni siquiera «el número de personas que se unieron para perpetrarlo». Lo es más bien el sinsentido ideológico que las causó, la mecanización de su ejecución y el cuidadoso y calculado establecimiento de un mundo de muertos en que nada tiene ya sentido" 20 .

Pero estas nociones extremas de "anti-mundo" y de "mundo de la muerte", que se plantean en oposición a categorías filosóficas centrales, siguen cercadas -ia qué negarlo?- por la duda de ser también metáforas desproporcionadas, expresiones cuya forma gramatical negativa denotaría antes que nada el artificio de su construcción. No creo necesario argumentar aquí contra esta apariencia evocando por ejemplo que fueron inciertos sucesos militares los que determinaron la desaparición, en lugar de la generalización, de los "laboratorios" de la dominación total. Prefiero, casi al contrario, apoyarme en la duda para dar a la reflexión el último giro conceptual, que de nuevo encuentra apoyo en ambos pensadores. Pues Fackenheim defiende que sólo el acontecimiento mismo, el hecho de haber ocurrido, permite creerlo y creerlo posible, y hace

${ }^{18}$ Op. cit., 180-181. Heidegger hace uso de la expresión en el ensayo "Superación de la Metafísica”, en: Vorträge und Aufsätze, Tubinga, Neske, ${ }^{2} 1959$, p. 92.

19 Op. cit., p. 265.

20 "Social Science Tecniques and the Study of Concentration Camps", en: Essays in Understanding 1930-1954, p. 243. En el mismo sentido, Los orígenes, p. 651. 
suya la paradójica tesis de Hans Jonas, en vista de esta novedad, de que "fue real mucho más de lo que es posible" ${ }^{21}$. O dicho de otro modo, ha ocurrido algo, un mundo, que, mirado de más cerca, no tiene condiciones de posibilidad, y sí sólo de su realidad. En la misma dirección, Arendt destaca cómo la realidad devastadora en que sobrevivían los internos producía a la vez una formidable sensación de irrealidad -tantas veces testimoniada-; los propios captores, como agentes humanos del proceso sobrehumano que antes que nada exigía de ellos desechar que matar hombres o niños tuviese algo que ver con cometer asesinato, participaban de otro modo de la atmósfera extrema de irrealidad. Lo imposible hecho posible día tras día y trasmutado en necesidad inexorable por sobre toda utilidad o interés, se revela así, a la luz del mundo (no dominado) de la vida, como la "realización completa del sinsentido"22; ha ocurrido algo, un mundo, que, mirado de más cerca, parece tener condiciones de imposibilidad, algo que parece realizar en acto el sinsentido de un anti-mundo.

No está claro que estas versiones comporten una deformación ilegítima de las categorías de la modalidad. No al menos si uno se mantiene en la perspectiva filosófica cuyas cimas son precisamente Husserl y Heidegger, y en la que tanto la posibilidad lógico-formal como la posibilidad real de los estados de cosas, y en suma la idea de mundos posibles, se sostiene sobre un fondo previo y pretemático de sentido, siempre supuesto, siempre en vigor. Este suelo intuitivo de sentido, no inferido ni inferible, es justamente el mundo como fenómeno universal dado a la experiencia presente y al recuerdo inmemorial; "el" mundo, que se ofrece existiendo antes de toda modalización parcial, como condición de ella, y existiendo simpliciter antes de toda operación formal que lo transforme proposicionalmente en "un" mundo entre múltiples posibles, como condición también de ello. Así, pues, en este planteamiento, el mundo dado en y por la experiencia no sólo existe sin necesidad de mediación por la posibilidad -es "protocontingencia" a la base de toda relación ideal-, sino que en cierto modo encierra el todo de sentido que hace precisamente posibles los reinos de posibilidades fingidas o pensadas, pretéritas o futuras. Ahora bien, las estructuras de este mundo originario y fundante remiten por principio a dinámicas intencionales de sentido de la vida intersubjetiva, de la coexistencia; tienen por tanto una lógica propia -“trascendental”- que sólo se conjuga en primera persona del singular y del plural. De aquí que si estas estructuras de sentido resultan vulnerables a una trasgresión interna y sistemática que, como lógica de destrucción, no puede ni incorporarse a ellas como modificación

${ }^{21}$ Op. cit., p. 230-233

${ }^{22}$ El ensayo "Social Science and Concentration Camps" incluido en Essays in Understanding 1930-1954 se tradujo al alemán bajo ese título sacado del propio texto de Arendt. Puede leerse en el volumen Nach Auschwitz, Berlín, Tiamat, 1989. 
parcial de su sentido, ni concebirse a partir de ellas como posibilidad abierta de su desarrollo; si el supuesto testigo acertó al hablar de "asesinato político del mundo" y de "asesinato de la conciencia del mundo" ${ }^{23}$, puede entonces asumirse con cierto criterio que lo imposible ha sido hecho posible y que el sinsentido absoluto, que por serlo carece de condiciones, se ha hecho realidad. Arendt dice lo mismo, aunque la expresión sorprendentemente pierda mucha fuerza, cuando afirma que el mal ha sido hecho radical.

\section{Banalidad del mal e inautenticidad del pensamiento}

Aun siendo un hito perturbador en la historia de la ética, el concepto kantiano de un "mal radical" en la naturaleza humana -al que se debería que el sujeto humano busque siempre algún móvil de la acción que añadir a la conciencia escueta del deber, como si ésta nunca bastase para determinar la conducta-, apenas puede considerarse más que un antecedente verbal del mal que pone por obra la realización de una conditio inhumana en un mundo de otro género. La cualidad única del mal y del todo de horror que la Historia ha dado a conocer también a la filosofía, se pone indirectamente de manifiesto en el hecho de que no habría respuesta humana posterior que pudiera ser adecuada a la gravedad del crimen, conmensurable siquiera lejanamente con él: la persecución legal se encuentra con algo "incastigable", la persona superviviente ante algo "imperdonable, invengable". A la altura de Los orígenes del totalitarismo diríase que Arendt juzgaba que la naturaleza absoluta del crimen acontecido hacía imposible asimismo la comprensión de la perversidad "ideológica” de sus perpetradores, más allá del vicio y del interés ${ }^{24}$. La llamativa tesis posterior de Arendt acerca de "la banalidad", no ya de algún implicado en particular entre tantos miles de ejecutores, sino del organizador por excelencia de la maquinaria administrativa de matar, pareció entonces que alteraba la comprensión del horror y trastocaba de manera desconcertante el aspecto sobrehumano e infrahumano a la par -pero ya no humano- del universo paralelo. Como es sabido, la provocativa expresión de Arendt, llevada al subtítulo de Eichmann en Jerusalén (1963), dio lugar a innumerables discusiones y confusiones. Pero lejos de ver en "la banalidad del mal" una atemperación metafísica del anti-mundo, o bien una reconciliación con la humanidad de los ejecutores por vía de una psicología profunda -al cabo dos posibilidades familiares en la historia de la filosofía-, el sorprendente hallazgo viene a completar,

${ }^{23}$ Zvi Kolitz, Iosl Rákover habla a Dios, -trad. de Eliahu Toker- Buenos Aires/México/Barcelona, FCE, 1998, p. 23.

${ }^{24}$ Op. cit., 680. 
todavía insuficientemente quizá, el estupor del que el pensamiento debe tomar nota.

La tesis de Arendt de la banalidad del mal describe en primera instancia una desproporción. Un personaje normal hasta casi la vulgaridad, sin rasgos psicóticos ni fanáticos, reacio a las proclamas ideológicas, al que repele la visión del dolor físico, un tipo "que habría sido incapaz de matar a su jefe para heredar el cargo", desempeña un puesto clave en la gigantesca empresa de destrucción. El jefe de la oficina móvil que llevó a cabo la compleja labor administrativa de identificación, reunión y control de la población judía, y que ordenó con máxima eficacia el complejo dispositivo técnico que permitía su deportación ininterrumpida desde distintas sociedades europeas con distintas "sensibilidades" y múltiples autoridades interpuestas, todo ello en medio de una guerra, este hombre concebía su actividad como un trabajo de oficina que desarrollar con la mentalidad, el lenguaje, las actitudes y los valores propios del funcionario exigente. La desproporción proviene, pues, precisamente de la escalofriante "normalidad" del ejecutor, de su personalidad común y sus móviles completamente corrientes -cumplir con su país, cumplir con su deber, hacer carrera profesional-.

Pero la tesis de Arendt conecta, en segunda instancia, con el diagnóstico de que tal "normalidad" nace de la ausencia total de pensamiento en el individuo. De lo que carecía quien no cesaba de calcular y ordenar, de tomar medidas y disponer medios, no era desde luego de inteligencia, sino de una detención y atención reflexiva al sentido de lo que él hacía y de lo que veía hacer a su alrededor. Decir que un individuo tal "no pensaba" es en realidad decir que la experiencia de las cosas y los hombres, la experiencia del mundo que con bastante espontaneidad y naturalidad nombra el bien y el mal, se había en su caso perdido por entero, y que la pérdida no parecía haber dejado secuelas en el personaje. Las cuestiones que en instancias superiores habían sido objeto de estipulación y decisión ideológicas se resolvían en un proceso administrativo y técnico, y la reflexión, el pensamiento o, lo que es lo mismo, la experiencia en la presencia directa de los hechos, era ya irrelevante, estaba fuera de juego; de hecho podía tratársela como una debilidad, una tentación indigna o residuo natural de compasión para el que no había lugar en la nueva construcción de la realidad. "Banalidad del mal" reúne, en suma, una pluralidad de fenómenos que se dejan agrupar todos en torno al pensamiento (a la experiencia reflexiva): no había por qué pensar ni se debía pensar; pensar no llevaba a nada; y tampoco había nada que pensar, pues ya otros lo habían pensado y ordenado por todos, y en fin, nada pasa o nada cambia en la vida de uno por no pensar. 
No cabe duda de que la tesis de la banalidad del mal así planteada no era aplicable indistintamente en las distintas esferas del mundo totalitario. Alguno de los más lúcidos corresponsales de Arendt no dejó de señalarle, con motivo de la publicación del libro, la inviabilidad de su análisis si el acusado en el Tribunal de Jerusalén hubiera podido ser Goebbels y no Eichmann ${ }^{25}$. Y no es preciso volver a mencionar el furor de la tortura en los campos de la muerte, que daba fin al aséptico trabajo de Eichmann. El fenómeno de la banalización del mal sí resulta significativo, en cambio, para entender, con ayuda de las categorías ya empleadas, cómo el universo totalitario extiende a su alrededor una pasividad colectiva que es imprescindible a la consecución de sus objetivos. En muy otra escala de gravedad, por tanto, respecto del modelo in individuo que observó Arendt en Jerusalén, los rasgos de rechazo de la reflexión, vaciado de la experiencia, impasibilidad de la persona, aparecen también en el "buen padre de familia" alemán -pero no sólo alemán- que tampoco era quién para hacerse opiniones sobre lo que veía pasar y que en consecuencia se entregaba con dedicación ejemplar al cumplimiento de sus tareas profesionales; recluido en la esfera profesional y en la vida privada como los únicos ámbitos de su incumbencia y responsabilidad, dejaba "todo lo demás" a los que conocían y dirigían los destinos de la Historia. Esta compacidad de la normalidad en medio de las convulsiones forma así parte integral del universo totalitario (más amplio que el concentracionario, que es su centro). El hombre "normal" se aferra al mundo cotidiano de la vida, con sus fines y sus rutinas, su sentido y su trama de relaciones humanas, como si "las cosas" siguieran su curso más o menos natural, como si no estuviese roto el tejido de coexistencia que sostiene el mundo. De suerte que si todo era ya posible y era ya real, al mismo tiempo "todo" podía y debía operarse bajo un signo de normalidad, y todo podía trasmitirse al mundo intersubjetivo bajo la apariencia de ser reintegrable, mal que bien, a la experiencia humana.

El hallazgo arendtiano de esta normalización individual y colectiva del mal ha tenido un enorme reconocimiento posterior y es hoy una clave conceptual de múltiples análisis históricos, psicológicos y sociológicos sobre el Holocausto. Lo cual entraña el peligro de convertir en tópico un fenómeno que llamaba a la perplejidad y que demanda por ello, en otro sentido, una reflexión filosófica. A mi entender, los planteamientos que se limitan a explorar los factores objetivos genuinamente modernos que estaban a la base de la catástrofe y que incluso podían empujar hacia ella -hacia la catástrofe del hecho y hacia la catástrofe del juicio-, no siempre reparan en este riesgo de, en virtud de una explicación

${ }^{25}$ Se trata de J. Glenn Gray. Apud: Elisabeth Young-Bruehl, Hannah Arendt, Valencia, Alfons el Magnànim, 1993, p. 472. Sobre las dudas de Jaspers pueden consultarse las cartas 337 y 345 del epistolario con Arendt: Briefwechsel 1926-1969, Múnich, Piper, 1985. 
genérica, normalizar, por así decir, lo atroz y la propia normalización de lo atroz. Ya se ponga el acento en la estructura burocrática deshumanizada con que la administración moderna, en el anonimato libre de valores, ejerce el monopolio del poder, ya en el desarrollo de la técnica que revierte sobre el mundo humano su potencia infinita, en ambos casos se difumina el principio de que la realidad en acto del antimundo, del mundo de la muerte -no exactamente, sólo, un genocidio moderno-, trascendía sus propias condiciones de posibilidad, y como fin último absoluto del totalitarismo nazi, exigía la redefinición, la reconstitución totalitaria de todos los factores y elementos que sirvieron a su realización; la mayoría de los cuales, y los más determinantes, resultan sin duda distintivos de la Modernidad. En todo caso, sí parece difícil abrazar este peligro con menos reservas, y por ello de modo más ilustrativo, que las que empleó Heidegger en su única mención pública al asunto que nos ocupa. En pocas palabras, y dichas por sorpresa al hilo de una extraordinaria meditación sobre la técnica, es la técnica como destino histórico la que resulta la condición absoluta del acontecimiento, al extremo de que ella y sólo ella, en su proceder anónimo, viene a agotar la esencia del hecho y a constituir a la vez su descripción última y su comprensión explicativa: "Merced a tal disposición la Tierra se convierte en una cuenca carbonífera, el suelo en yacimiento. Este disponer es ya de otro género respecto de aquél por el que el campesino dispuso en otro tiempo de su campo de cultivo. La labor campesina no desafía al suelo cultivable; más bien entrega la siembra a las potencias de crecimiento; las protege en su germinar. Pero entretanto también la disposición sobre el campo ha pasado ya a ser la misma dis-posición que trasmuta el aire en nitrógeno, el suelo en carbón y mineral, el mineral en uranio, el uranio en energía atómica, y ésta en destrucción disponible. El cultivo del campo es ahora una industria alimenticia motorizada, en esencia lo mismo que la fabricación de cadáveres en las cámaras de gas y en los campos de exterminio, lo mismo que el bloqueo y la condena de países al hambre, lo mismo que la fabricación de bombas de hidrógeno"26.

En la obra de Fackenheim, mas también en la de Günther Anders, se encuentran, en cambio, elementos de reflexión que enriquecen y problematizan la constatación de la banalidad del mal. El segundo de estos pensadores parte igualmente de la desmesura del mundo técnico y del abismo que abre entre lo que el hombre es capaz de fabricar y lo que es capaz de representarse de la realidad que él mismo crea. La desmesura es tal que nuestro mundo -llega a decir Anders- ha dejado de ser realmente "nuestro". Ya que viviendo

${ }^{26}$ Conferencias de Bremen (1949), en: Gesamtausgabe 79, Fráncfurt, Klostermann, 1994, p. 27. 
en medio de lo que nos excede se cumple una singular "ley de la caída": "cuando deviene desmesurado aquello ante lo que habría inexcusablemente que reaccionar, se produce una caída en nuestra capacidad de sentirlo (unser Fühlen)"27. "Sentir", sentir la realidad; el viejo concepto para la captación de valores o disvalores de cualquier orden y para la reacción del ánimo ante ellos, noción tan vieja como que es anterior a la Primera Guerra, es a la que Anders recurre aquí en vista de la pérdida "no sólo del sentimiento de horror o de consideración o de compasión, sino también del sentimiento de responsabilidad" 28 . La ley infernal de la caída se precisa entonces como la proporción creciente en que cada uno de estos sentimientos, y todos en conjunto en torno al "sentir responsabilidad", pierden fuerza, y en el límite se desactivan, conforme aumenta el efecto y el impacto de lo que la acción colectiva y técnica engendra. Ahora bien, de ello, con ser tan decisivo, no se extrae una comprensión motivacional última de quien puso su acción al servicio de una nueva, inaudita e incomparable dimensión de lo monstruoso; para cuya planificación técnica y puesta en marcha organizativa tenía que representarse el resultado final del proceso. Hay más bien una segunda posible caída por debajo del suelo de la caída afectiva, un vuelco de segundo grado que convierte la dificultad a la hora de percibir y de sentir un mundo mecanizado, en autojustificación incondicional de la propia acción. El desmayo del sentimiento y de la responsabilidad sirve ahora, más bien, de apoyo o de trampolín para dejar ir todo asomo de afección, y todo resto de reflexión. Con lo cual, antes que el burócrata en ejercicio, aparece aquí la figura del "hombre que advirtiendo el peligro de destrucción completa a su alrededor decide volverse él mismo una fuerza destructiva" 29 .

En un sentido muy semejante es en el que Fackenheim se refiere a "la banalidad del mal" como "sólo un pensamiento a medias y sólo media verdad"30. También él recurre a detalles reveladores del comportamiento del propio Eichmann, distintos de los señalados por Arendt, pero el fondo de su reserva apunta a que un jefe dentro de la máquina totalitaria o un colaborador intermedio o un ejecutor hacían, día tras día, un voto íntimo de adhesión justamente a que todo pudiese ser posible; y a que, en la parte que de ellos dependiese, lo fuese además como necesidad que se opera con entera normalidad. La máquina de matar requería eslabones humanos, y nunca faltaron hombres que se prestaran a hacer de sí mismos algo semejante a engranajes de la máquina.

27 Wir Eichmannssöhne, Múnich, Beck, ${ }^{2} 1988$, p. 28.

28 Wir Eichmannsöhne, p. 29.

29 Arendt, "Approaches to the «German Problem»", en: Essays in Understanding 1930-1954, p. 111. Vid. también Los orígenes del totalitarismo, 515-517, 524-525.

30 To Mend the World, p. 237. 
La desproporción abismal entre el crimen totalitario y sus servidores se allana, pues, en un cierto sentido. La "ausencia completa de pensamiento" revela un rechazo inconmovible a pensar, a percibir, a sentir, a sentirse; la banalidad del mal, la determinación inquebrantada a cegar toda experiencia.

Para Fackenheim, la sólo media verdad de la banalización del mal, reintegrada al todo del totalitarismo y de su empresa definitoria, viene así a significar, a la manera de Steiner, el fracaso de todos los intentos por hacer comprensible el Holocausto; de los intentos penúltimos en la psicología, sociología e Historia, y de los supuestamente últimos de la filosofía. Los ensayos globalizadores que lo insertan en un destino histórico y de este modo creen hacerlo comprensible, incurren en lo que él tacha de "pensamiento inauténtico después del Holocausto"; pues juzgan del acontecimiento sin confrontarse con él, sin exponerse a su singularidad, reintegrándolo a conexiones más amplias de sentido, ya sea ésta la del nihilismo de la era técnica. Pero "donde está el Holocausto no hay superación; y donde hay superación no está el Holocausto" 31 . Mientras que los ensayos analíticos que sí se aproximan a mirar el universo del que el Holocausto es centro, recurren al cabo para su conceptuación a nociones recibidas (mal radical, mal demónico, banalidad del mal) que resultan insuficientes. Para el pensador judío este fracaso del pensamiento tiene algo de inevitable, ya que la comprensión teórica no sabría evitar que el antimundo, el "todo de horror", cobre el aspecto comprensible de un mundo, mal que bien reconocible en una Historia unitaria. De aquí que la cuestión a la que Fackenheim se ve abocado es, al contrario, la de si la Historia contemporánea, que ha revelado que los hombres parecen no sólo capaces de todo sino capaces de dar a este "todo" un alcance impensable, si esta Historia fáctica no deja atrás sin remedio al pensamiento mismo y a su Historia interna y externa.

\section{De la responsabilidad política de la filosofía y de la continuidad del} pensamiento

Pero antes de examinar si el pensamiento filosófico después de la catástrofe puede seguir estando a la altura de su tiempo en algún sentido no trivial, se impone una consideración previa acerca de la tan discutida responsabilidad del pensamiento filosófico en el origen de la catástrofe. Y para ello retornaré por última vez a los planteamientos de Arendt.

Nunca se ha propuesto una comprensión del totalitarismo, en particular del nazismo, que, manteniéndose en el plano del análisis histórico-político e

31 Op. cit., 135. 
e incluso motivacional, se valga de categorías filosóficas en medida tan amplia y fundamental como hace Arendt en su gran obra; categorías y conceptos antiguos (posibilidad, necesidad, verdad, todo, mal, etc.), que sirven para describir una novedad absoluta, no para reducirla. Este enfoque reviste por ello especial importancia de cara a la delicada cuestión de las conexiones entre la tradición filosófica occidental y el novum del totalitarismo. En razón de su particular carga teórica, podría quizá conjeturarse que pocos ensayos de comprensión se encontrarán en mejores condiciones que el de Arendt para levantar un acta global de recusación contra la tradición filosófica. Y, sin embargo, la situación es justamente la contraria: quizá nadie como Arendt ha defendido de una manera tan rotunda e inequívoca la ausencia completa de responsabilidad de la tradición filosófica en la catástrofe. En un ensayo que vio la luz cuando todavía funcionaban en Europa las factorías de la muerte, Arendt se atrevía a proclamarlo sin ambages: "Lo que es cierto de la historia política alemana es incluso más verdadero de las raíces espirituales que se atribuye al nazismo. El nazismo no debe nada a ninguna parte de la tradición occidental, ya sea germana o no lo sea, sea católica o sea protestante, sea cristiana, griega o romana. Puede que prefiramos a Tomás de Aquino o a Maquiavelo, o a Lutero, o a Kant, o a Hegel, o a Nietzsche -y la lista puede prolongarse indefinidamente, como revela un vistazo sumario a la literatura sobre «el problema alemán»-; el caso es que ninguno de ellos tiene la más mínima responsabilidad por lo que está ocurriendo en los campos de concentración. Hablando en términos ideológicos, el nazismo empieza sin base tradicional ninguna en absoluto, y mejor sería percatarse del peligro inherente a esta radical negación de toda tradición que fue el rasgo principal del nazismo desde su comienzo (no así del fascismo italiano en sus primeros momentos). Al fin y al cabo, fueron los propios nazis los primeros en rodear su completa vaciedad de las cortinas de humo de las interpretaciones cultas. La mayoría de los filósofos que hoy son calumniados por estos más que celosos expertos en el problema alemán, ya los habían reclamado los nazis como suyos; no porque a los nazis les importase lo más mínimo la responsabilidad, sino simplemente porque advirtieron que no hay mejor escondite para las propias intenciones que la gran palestra de la Historia, ni mejores guardaespaldas que los niños que juegan en la palestra, estos «expertos» tan fáciles de utilizar, tan fáciles de engañar"32.

La tesis de Arendt -contra tirios y troyanos- es, pues, la ausencia global de responsabilidad de la filosofía en los sucesos totalitarios. De la Historia del pensamiento no cabría desprender ningún nexo significativo que prefigurase en concreto la idea de verdad como fabricación de la realidad por el terror, ni ninguna influencia real que haya motivado la contraposibilidad de un mundo

32 “Approaches to the «German problem»", p. 108. 
de la muerte o la normalización colectiva del mal radical. La llamada hitlerización del imperativo categórico, o la conversión del Estado racional hegeliano en Estado criminal, o la mutación del sí unánime a la vida terrena en organización masiva de exterminio y en voluntad de destrucción -por citar algunas de las asociaciones recurrentes-, dicen algo de las mixtificaciones nazis, y nada en realidad de las filosofías que son así objeto de brutal manipulación. De hecho, y como ya se señaló, la ideología totalitaria por su misma peculiaridad sólo podía tener sentido en proceso, en acción; sólo podía concebirse en la escala de los hechos. La extensión más o menos indiscriminada de responsabilidad a la tradición europea lleva más bien a perder de vista, como señala Arendt, la empresa decisiva para el totalitarismo de hacer quebrar internamente esta misma tradición, de destruir no sólo su vigencia y expresión oficial, institucional, sino también su latencia, con todas sus dimensiones subyacentes, morales e intelectuales ${ }^{33}$.

Así y todo, es dudoso que el asunto pueda darse por concluido en el punto del análisis en que Arendt lo deja. A mi entender, el alegato de una inocencia completa de la tradición íntegra de pensamiento exige una prolongación problemática que la autora de La condición humana no pareció advertir. Y es que al aceptar Arendt la novedad del totalitarismo emergiendo de la quiebra de la tradición, y al ofrecer al mismo tiempo una descripción cabal de la terrible novedad sobre la base de categorías del pensamiento, parece inevitable asumir que el empeño constitutivo de la tradición filosófica: "pensar el Todo"-"pensar el orden de lo posible" se sostenía en verdad sobre un suelo de una precariedad radicalmente más honda de lo que nunca la filosofía había alcanzado a representarse. Dicho en otras palabras, si "los hombres normales no saben que todo es posible" -lema del tercer libro de Los orígenes del totalitarismo, sacado de las memorias de un superviviente-, si ni siquiera sospechan qué pueda querer decir tal cosa, el pensamiento que se tenía a sí mismo por crítica universal de lo que puede haber y la cultura europea de Ideas a que este pensamiento dio lugar, compartieron hasta el final esta suerte de tranquila ignorancia, esta suerte de actitud natural instalada en un mundo normal de la vida y en un mundo de la Historia, transformables ambos pero ninguno de ellos anulable. Entre las posibilidades históricas no podía por principio contarse el espectro de una pretensión que fuese enteramente otra respecto de la filosofía, pero que se proyectase asimismo sobre el todo de la realidad, como enteramente destructiva del todo de la libertad humana, como cancelación interna de la propia condición humana. La sola idea de una "alternativa" semejante a la

${ }^{33}$ Con esto nada se dice, ciertamente, acerca de las responsabilidades individuales de unos u otros filósofos profesionales en los años de la catástrofe o en la etapa previa, como tampoco del comportamiento de las instituciones científicas. 
totalidad de la vida, y el solo pensamiento de que pudiese socavar el suelo de la realidad por la vía de los hechos, se anulaban a sí mismos -habría que decir- como lo no pensable, como un verdadero sinsentido que en la realidad es nada. El que todo ello haya ocurrido (la verdad contra-fáctica por el terror, la contraposibilidad del antimundo, la mutación de la libertad racional en eslabón banal de una máquina de crímenes inhumanos), y el que de algún modo se deje expresar conceptualmente, filosóficamente, o sea, en el propio lenguaje del Todo, precisamente como totalitarismo, como totalización afilosófica, revela, pues, además de la inocencia justamente alegada de la tradición filosófica, una inocencia de otro orden: una ingenuidad de apariencia insuperable, un punto ciego que habría acompañado al pensamiento "de Jonia a Jena", y luego de Jena a Friburgo, respecto de la dimensión y la cualidad que el mal puede cobrar inmanentemente en relación universal con el todo del mundo de la vida y de la Historia.

Y en este punto de desarrollo sí se puede establecer ya una conexión inmediata de sentido con la meditación más original y relevante del gran libro de Fackenheim. Ésta arranca de la sospecha de que "el Holocausto pueda ser una ruptura radical en la Historia, y entre las cosas rotas se encuentre no ya esta o aquella forma de pensamiento filosófico o teológico, sino el pensamiento mismo"34. La ruptura radical proviene, claro está, de la unicidad radical del universo en que no sólo el hombre sino la Idea del hombre parece morir. Pero la aportación peculiarísima de Fackenheim consiste en advertir que el acontecimiento único encierra en realidad una doble e irreductible novedad. No se trata, pues, de que los archivos de la Historia guarden memoria de un caso parangonable, sino de que en el interior mismo del antimundo que Treblinka o Auschwitz nombran ocurrió a la vez algo que tampoco cabía en modo alguno prever, ni cabe ahora explicar, a saber: el hecho de que "allí y entonces" algunos seres humanos opusieron una última resistencia al todo del horror; y lo hicieron en forma de una adhesión consciente a la vida humana en el trance de su aniquilación sistemática. En una expresión que se quiere exacta bajo su apariencia paradójica, se trata de que la lógica de la destrucción, siendo humanamente irresistible, halló resistencia humana, fue resistida. El universo que paraliza por igual las categorías de la vieja y de la nueva filosofía, y, hundiendo su suelo, parece descoyuntarlas, no llegó a paralizar del todo a seres humanos que al sufrirlo en vivo lo captaron adecuadamente, y al "comprender" la condición última de la voluntad de destrucción opusieron a ella un movimiento de resistencia, una reacción irreductible a fin de que ni siquiera allí todo fuese posible. Fackenheim trae al recuerdo y a la reflexión un puñado

${ }^{34}$ Op. cit., 193 -subrayado del autor-. 
de acciones y decisiones "heroicas" en la infinita indefensión -llámemoslas así, y aceptemos el pudor de no reproducirlas-; todas ellas resultan inexplicables desde una dinámica intencional del interés o una inconsciente del deseo, o en razón de algún resto de voluntad de poder, y son ajenas y contrarias a la ley del campo para los internos (la búsqueda de la supervivencia individual imposible). La novedad de esta resistencia precaria desde el absoluto desamparo y por adhesión a "briznas de humanidad" cobra así un valor de ultimidad y tiene, estrictamente a la vez que la novedad a que responde, un estatuto ontológico; no sólo accede a una captación auténtica, a una comprensión "en persona" del totalitarismo, sino que revela en acto y por el acto la existencia de acciones humanas "al nivel" de la agresión perpetrada. Sobre ambos aspectos en unidad descansa -concluye Fackenheim- la posibilidad incierta de la vida humana de después del Holocausto y la de un pensamiento de después del Holocausto.

Pero, sorprendentemente, esta consideración no podría garantizar por sí sola una recuperación de la filosofía en el caso de que la filosofía como tal no acertara a reconocer en la Historia de su disciplina -prosigue Fackenheim ahora- algún hecho análogo a esta novísima resistencia, algún acontecimiento de estructura y sentido siquiera aproximables. Si el pensamiento filosófico "de entonces" no ofreciese ningún ejemplo efectivo de afinidad con la novedad de segundo orden, la filosofía como tal quedaría expuesta de lleno al impacto de la novedad de primer orden; no habría para ella nova sino únicamente novum totalitario. Y es así como el autor judío trae a colación, para desconcierto grande de nuestros hábitos hermeneúticos, la historia siempre medio olvidada de ese "oscuro profesor alemán" de la Universidad de Múnich que, "en medio del propio Ereignis", advirtió el signo de los tiempos.

Kurt Huber, Profesor de Filosofía y Psicología, era también un hombre normal; ni un genio ni un gran creador, sólo un estudioso de Leibniz y de la tradición de filosofía clásica alemana que se daba por desfasada y que el régimen hacía objeto de apropiación perversa. Sabedor de que su acción estaba abocada con gran probabilidad al fracaso, y de que a cambio ponía en riesgo seguro su vida, su carrera y su familia, Huber alentó el grupo de resistencia estudiantil "La Rosa Blanca" y redactó él mismo varios de los panfletos que instaban a la resistencia pasiva, y más tarde a derrocar al tirano y al terror -como en el postrero que se lanzó en la Universidad muniquesa el 18 de febrero de 1943-. Ante el Tribunal del Pueblo que sin defensa letrada lo condenó a muerte, Huber preparó un alegato final, cuyo borrador se ha conservado, y en el que invocaba como máxima de su acción el imperativo universalizable de poner principios morales a la base de la legalidad; evocaba también la idea del derecho no escrito, recordaba el vínculo racional entre libertad y 
responsabilidad, así como la dignidad intrínseca al desempeño de la cátedra, para apelar finalmente a "la voz de la conciencia" y hacerlo en la formulación extrema de Fichte que asume una responsabilidad moral universal de cada alemán por la suerte de todas las cosas que tienen lugar en Alemania ${ }^{35}$.

Pero para Fackenheim no se trata aquí de un rescate in extremis de determinados fragmentos de la filosofía y de la cultura europeas, por fundamentales que sean, gracias al testimonio de un solo individuo, por admirable que éste sea. El asunto es otro. Y apunta a la debilidad radical, extrema, irrisoria, de los principios e ideas a que apelaba Huber, dado que ellos, e igual que ellos cualquiera de sus alternativas teóricas conocidas, cualquier idea del hombre o del pensamiento o del lugar del hombre en el todo, habían sido expulsados de hecho y de derecho, por activa y por pasiva, del nuevo orden del mundo, del todo en que ahora volvían a pronunciarse como cayendo de ninguna parte. Los pronunciaba además un "hombre normal", o sea, débil, que, a solas con su pensamiento frente a la normalidad ambiente, actuaba sin mirar consecuencias. Como antes seres humanos al borde de la destrucción última mostraron una última adhesión libre a la condición humana, aquí el pensador de profesión sacó también su fuerza de resistencia de la Idea debilitada del pensar, de la posibilidad, que ya había quebrado, de la verdad y de la vida en la verdad, y así, como por añadidura, su acción entreabrió un nuevo margen de precariedad a la Idea misma. Fackenheim propone un topos judío para designar esta forma de encrucijada histórica y de movimiento de la existencia individual, en que dos debilidades distintas pero vinculadas se refuerzan en su propia línea de ruptura, y sólo en ella, recomponiéndose o reparándose de y desde su propio quebrantamiento. La consecuencia ya se anticipó: "Este Tikkún, allí y entonces, creó la posibilidad y la necesidad de una filosofía después del Holocausto, aquí y ahora. Que no podrá consistir en un retorno a la filosofía desfasada de Huber -o de ningún otro-. Que más bien debe traer a una conciencia filosófica de después del Holocausto el Tikkún realizado por Huber por mor de una filosofía desfasada. La Idea de hombre puede ser -ha sido- destruida, dado que la humanidad puede ser -fue- destruida. Pero precisamente porque la humanidad misma del hombre ha sido recompuesta, reparada -en algunos hombres y mujeres por algunos hombres y mujeres-, la Idea del hombre puede ser reparada"36.

No es ya momento de examinar si la filosofía contemporánea cuenta con conceptos que señalen en una dirección próxima a la experiencia judía del

35 Puede leerse íntegro en: Inge Scholl, Die Weisse Rose, Fráncfurt, Fischer, ${ }^{3} 1995$, p. 68-70. (Hay traducción catalana de Esther Roig, Barcelona, Columna, 1994.)

${ }^{36}$ Op. cit., 276. 
Tikkún ${ }^{37}$. Al final de mi exposición no queda sino anotar por última vez lo sorprendente del panorama teórico en su conjunto, tal como se presenta al tratamiento a dos voces que he seguido. El novum espeluznante, que la filosofía tiene que mirar y que aprender a ver, saca de la realidad al hombre, al pensamiento, al mundo del hombre y del pensamiento; el novum forma parte del siglo, sucede en las condiciones de la Modernidad, pero ni la Historia ni la filosofía de la Historia pueden hacerse cargo de la ruptura que trae. El segundo novum, la novedad que lo es doblemente a posteriori, recompone en el lugar y tiempo del desastre la posibilidad ya deshecha del hombre y del pensamiento y del mundo de la vida, y deja un legado de pura precariedad. A la filosofía de después de ambas novedades se le ofrece así no una nueva navegación, no un retorno a fuentes teóricas perdidas, no una espera serena que distraiga de la conmoción; más bien -se atreve a pedir el intempestivo pensador judío- una "escolarización" en que la vida reciba una nueva oportunidad de enseñar al pensamiento. No es una crítica por mi parte, ni puedo ya precisar mi opinión, pero creo que cuando Fackenheim califica el juicio a Kurt Huber como el proceso de mayor relevancia para la filosofía occidental desde la condena de Sócrates está dando pie a pensar que el filósofo del tiempo presente y la propia filosofía pueden reconocer con alguna claridad la necesidad, que es afán, de esta suerte de escolarización.

${ }^{37}$ Pienso sobre todo en la descripción de Jan Patocka del que llama "tercer movimiento del alma humana". Al respecto puede verse mi ensayo "Tres perspectivas sobre la fenomenología en su siglo", en: Diálogo filosófico 46 (1/2000). 